\title{
James Edward FitzGerald (1818-1896)
}

\section{Intellectual of all trades and New Zealand's political meteor}

\section{EDMUND BOHAN}

Edmund Bohan is the current John David Stout Fellow and is working on a biography of James Edward Fitzgerald. This article is based on a seminar he gave at the Stout Research Centre on 6 September 1995.

It was William Gisborne who likened FitzGerald to a meteor, but the best sustained description of his qualities was possibly Dryden's satirical pen-portrait of Zimri, the Duke of Buckingham, in Absolom and Achitophel, 1680:

A man so various that he seemed to be,

Not one but all mankind's epitome;

Stiff in opinion, always in the wrong,

Was everything by starts and nothing long;

But in the course of one revolving moon,

Was chemist, fiddler, statesman and buffoon.

James Edward FitzGerald was in all respects the multi-talented Renaissance man, as even the barest list of his achievements will illustrate: colonial reformer, essayist, versifier and would-be poet (the least of his skills if by no means the least of his ambitions), artists, wood-carver, journalist, civil servant, politician, orator (perhaps the most outstanding of his time which was an age of orators), controversialist, farmer and singer. He even fancied himself as architect, and the oldest surviving building at Christ's College, Christchurch, is his work.

To be more specific, he was arguably New Zealand's first Prime Minister during the near farcical but disastrous first parliamentary session of 1854; he was certainly the first secretary of the Colonial Reform Society formed in London during 1849, first editor of the Lyttelton Times in 1851, and Canterbury's first Superintendent in 1853. As their Immigration Agent in London between 1858 and 1860 he acted as a powerful propagandist in all colonial matters through his close personal links with Gladstone, Lord Lyttelton, and Godley, and he worked tirelessly against both Governor Gore Browne's policies in New Zealand and Stafford's First Ministry - itself far from being in agreement with Browne's intentions. On his return to Canterbury, FitzGerald founded and edited The Press in opposition to W.S. Moorhouse's grandly imaginative

James Edward FitzGerald, as photographed by A.C. Barker. Canterbury Museum, Christchurch.

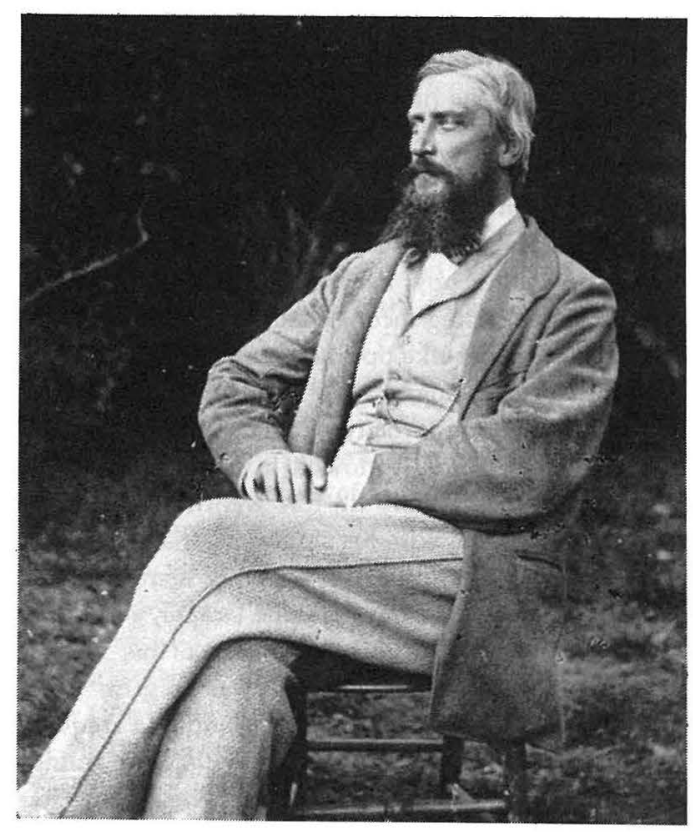

Lyttelton Tunnel and railway schemes and what FitzGerald stigmatised as the new Canterbury 'Yankeeism'; its reckless driving towards expansion which, he feared, was swamping the high morality of Godley's founding ideals.

Then, returning to colonial politics between 1862 and 1866 he won (in order) adulation, fame, and notoriety as a dynamic, inspirational but fundamentally divisive politician: champion of Maori rights through his great speeches of 1862 and 1863, yet unwittingly an inhibitor of those rights because his acute dislike of the pragmatic Stafford (himself determined to include Maori in parliament and government) forced him into political allegiances with Domett, Fox and Weld which delayed Maori attaining those rights. King-maker for Domett's Ministry in 1862, his inclusion in Weld's Ministry in 1865 precipitated its fall, and his strident, personal opposition to Stafford during 1866 cast him into a lonely and bitter political wilderness. At the same time his business affairs also reached their nadir as creditors closed around to edge him out of the Press towards imminent bankruptcy; until the despised Stafford made him first Comptroller General of Finance 
and Auditor - in which office he died, aged 78, in 1896, having been outstandingly successful and innovative and, in passing, a founder of the Public Service Association and first President of the Incorporated Society of Accountants.

In more than one sense Stafford gave FitzGerald a new lease on life: his health miraculously improved, he gained as much financial security as any hopeless businessman and failed farmer with (eventually) thirteen children could hope for; and he was able to indulge again, as he had in his London youth, the full range of his intellectual interests. It is unlikely, however, that his famous dinner-table impersonations of Stafford became any less frequent. Throughout his long life FitzGerald's wit sustained his wide personal popularity, no matter how exasperated people might become at his dazzling inconsistencies and impracticalities, his Micawber-like optimisms and Quixotic windmill-tiltings. MPs might wince beneath his oratory and repay his debating ferocity in kind; but after the debates when the brandy flowed in Bellamy's and the cigars were comfortably lit, few went home until he had charmed them with his singing of Irish songs.

Above all, FitzGerald was a family man; truly the beloved husband of Fanny Erskine Draper, and this is the one constant and unifying strand of his life. He was an indulgent father; certainly was no grim Victorian paterfamilias. When his rich friend and frequent source of loans, Henry Selfe, wrote with joyful tidings of his own son's academic successes, FitzGerald, desperately hard-up and anxious about how he could possibly educate seven children under the age of twelve, replied on 14 July 1865 :

The lads are very good but wild as hawks and to tell you the truth I am more like their elder brother than their father and they know it. A Maori writes to me yesterday from Auckland. "Oh Friend FitzGerald. Salutations to the father of the men, women, children, orphans, invalids, the Silly, the rich, the poor" etc. So I suppose my own family are the only ones who do not recognize my paternity.

Fanny Draper married FitzGerald when she was 18, against her angry father's advice after a stormy courtship. William Draper was rich and tyrannical and hated Fitzgerald. On Fanny's wedding day he ordered his household into mourning and had black drapes drawn across the windows of his Woburn Square mansion; his anger never softened and the angriest of FitzGerald's letters were all directed at William Draper. FitzGerald had been Fanny's brother's friend and had known her from her childhood, had helped educate her and regarded her, in an intellectual sense, as his Galatea. She was a pretty, petite, multi-talented girl who sang superbly in seven languages and was an accomplished pianist; she was widely read, an acute if often acerbic observer of people, and she was witty. She was from the first contemptuous of politics and politicians and, with excellent reason, blamed politics for his chronic ill-health and their own perpetual poverty. Everyone loved Fanny, and there are few letters from Canterbury's young leaders to the Godleys which do not remark on Mrs FitzGerald's latest witticism, state of health and wonderful management of husband and babies. During her first twenty-five years of marriage there were only seven in which she was not pregnant, and her last child was born when she was forty-three. The strains of life with FitzGerald and constant child-bearing must have taken a severe toll, yet she outlived James by four years - during which she fiercely defended his reputation against William Gisborne's dismissive verdict (in New Zealand's Rulers and Statesmen) and deeply mourned his loss.

James FitzGerald was a handsome man with a large and vivid personality and his contemporaries wrote about him continuously, recounting his latest often extravagant, exploits and states of health. He charmed, annoyed and fascinated people; he was never ignored, and many of his exploits have become part of Canterbury folk-lore: his flamboyant arrival at Lyttelton, his opening of the Sumner Road in his dog-cart (brilliantly reported by Crosbie Ward) and his death-defying driving of his famous cart - nicknamed the Circulating Medium - whose six-feet, scarlet wheels were so memorable a sight as he raced across ditches and rutted roads between Christchurch and his farm at Springs Station (now Lincoln University's campus).

His landing in 1850 was typically memorable. Always determined to be the first to do something whether it be to open the first Provincial Council, head the first Ministry or be first editor of Canterbury's first newspaper, he had throughout the voyage of the Charlotte Jane planned to be the first Canterbury Pilgrim ashore. Some days before landfall, however, he badly injured his knee while having a snowball fight with the ship's captain during a storm, but even that did not weaken his resolve. As the ship entered Lyttelton Harbour he forgot his damaged knee, dressed himself in a sailor's shirt, favourite green velveteen breeches and gaiters with mother of pearl buttons, and left Fanny in their cabin to endure a headache alone. As the ship's boat reached the jetty he vaulted over sixteen year old Hamilton Ward and achieved the honour of being first ashore. He then set off as fast as he was able up the steep path from the jetty and literally ran into his friend and hero John Robert Godley, who was hurrying down to greet the first arrivals and who at first scarcely recognized the bizarre figure enveloping him in long arms, in Charlotte Godley's words: 
'so altered by a sailor's dress, an immense straw hat, very hollow cheeks, a ferocious moustache, and I am sorry to say a lame leg'. When Godley realised who it was he "was so overcome as hardly to know whether to laugh or cry, and I believe ended by doing both'.

And here is his political and journalistic rival Crosbie Ward's description of FitzGerald:

[sitting] dabbing a screw of paper in the inkwell and drawing while other men talked in Canterbury's Provincial Council twelve years later: years of recurrent and often severe illness, anxieties, some successes but even more failures; debt-burdened but eternally optimistic that something would turn up and that he would still not only make his fortune in the following few months, but also defeat the reckless Moorhouse's Tunnel: 'But when he raises up his pale and prematurely aged-looking face, strokes his whitened beard, and casts his icy pale-grey eyes around the Council Chamber, you see at once there sits no common man. You strive to read his eye and brow, but as yet it is in vain, he is not easily unriddled. He reminds you rather of the Sphinx gazing with strong eyes straight through time to the confines of eternity, shunning all sympathy with what is human. Watch him closely, however, and hear him speak (and he gives you plenty of opportunities of doing so), and you may penetrate even the umbrous depths of James Edward FitzGerald ... To a mind well stored with facts he adds a powerful imagination and a caustic wit; from the aptitude he exhibits to detect fallacies in reasoning, latent principles of evil in specious propositions, and of reducing into order a chaos of ideas, it must be conceded to him that he possesses extraordinary powers of both analysis and synthesis. When he speaks it is with fluency and power. His emphases are good, his articulation clear, and his tone rich and sonorous; but he is merciless in his opposition and his ego is repulsive. Therein lies his weakness as a leader of a party, for however much his hangers-on (and there are several in the Council) may be dazzled by his brilliancy as an orator, few could abnegate themselves sufficiently to do all his bidding, and fewer still can love him. It is said that he feels himself too great even for his shadow, his fidus achates (Mr Brittan) and thinks a greater shadow might follow in the wake of so great a man.

To begin to understand FitzGerald one must start with his family background. He was an Irish gentleman, although born in Bath, England, and in common with all his class was as proudly familiar with his genealogy as any Maori rangatira of his whakapapa. And he had good reason to be proud of it. James was fifth son amongst 15 or 16 children of a rich absentee Irish landowner - Gerald FitzGerald of Coolanowle and Moate, Queen's County; a branch descended from the sixteenth-century Gerald, the great 11th Earl of Kildare. His mother was Katherine O'Brien, daughter of Sir Lucius O'Brien Bart. of Dromoland, Clare, and a direct descendant of Brian Boru, last and greatest of the Irish High Kings, killed by the Norsemen at Clontarf in 1014.

The FitzGeralds themselves boasted an equally exalted heritage. Few Irish families have so dominated Irish history and few others have produced such a dazzling array of dynamic and colourful characters who stirred their nation's blood in so many heroic causes and catastrophes. All branches of the vast clan were descended from the beautiful Welsh Princess Nesta, the 'Helen of Wales' - wife to Gerald of Windsor but also mistress of King Henry II, Stephen of Cardigan, and more than one Welsh prince. Her love affairs not only precipitated bloody civil war in South Wales but they changed the direction of Irish history, for from these various liaisons came her sons Meiler and Robert FitzHenry, Maurice and William FitzGerald and Robert FitzStephen; and their sons included Milo FitzGerald and Raymond le Gros. They were known by their contemporaries as 'Nesta's Brood' and were the Norman conquerors of Ireland; and the first great British historian who chronicled their deeds, Giraldus Cambrensis, was another of them. Nesta's Brood married daughters of the Gaelic chieftains and within a generation were Gaelic chieftains themselves, from whom descended not only the FitzGerald clans of Desmond, Kildare and the White Knights of Glyn, but the Burkes and many others. Much of Ireland's history from 1176 to the 18 th century is the personal history of the FitzGerald Earls of Desmond and Kildare.

Typically, James Edward FitzGerald laboured throughout his long life to prove his branch was the legitimate line from the 11th Earl of Kildare, but he laboured in vain; not even his eminent cousins supported his efforts. Gerald of Kildare had spent his youth under attainder for treason against Henry VIII, and during his journeys around the castles of his fellow earls and chieftains had a son, Gerald Oge, by Eleanor O'Kelly, daughter of the O'Kelly of Timogue. When Queen Mary Tudor pardoned him, however, he married the O'Dempsey's daughter and Gerald Oge was given merely the lands and status of superior gentry. FitzGeralds of Coolanowle and the O'Kellys maintained their claims to the Kildare earldom for centuries and perhaps with some reason. Bigamy was a frequent, not to say normal, practice in pre-Counter Reformation Ireland.

James Edward was a brilliant youth, but being so far away from any useful inheritance he had to rely on scholarships to pay his way through Cambridge, from whence he emerged with honours in the Maths Tripos and an insatiable interest in almost everything - from politics to painting, and from architecture to music He told wonderful stories, sang well, played the guitar and was at the centre of both fashionable Bath Society, 
which revolved around the poet and essayist Walter Savage Landor then at the height of his fame, and London's young upper-class intellectuals, who propounded their solutions to the world's problems at their debating societies and through such serious journals as The Spectator, Simmonds and Colonial, and The Times, Morning Chronicle and Morning Post. FitzGerald, by day a clerk at the British Museum with a brief to reform the Museum's cumbersome internal administration, wrote for all these papers. Landor was his literary mentor and model, Gladstone and his own relative John Robert Godley his political guides. FitzGerald seldom rated other people's abilities as highly as he rated his own; the great exceptions, indeed, were these three men - Landor, Gladstone and Godley - and each of them valued FitzGerald. Landor, who perhaps saw much of his own vast personality and large physical presence in the much younger man, patiently corrected his disciple's dreadful verse; Gladstone invited FitzGerald to call whenever he wished and during the 1890s quoted FitzGerald's ideas, with generous acknowledgement, during his most famous speeches on Irish Home Rule. Godley, a veritable paragon of his age, was unsentimentally aware of all FitzGerald's flaws but cherished him as, perhaps, his dearest friend.

In the 1840s FitzGerald's crusade against the Hudson's Bay Company and his widely publicised efforts to transpose a cross-section of Irish society to Vancouver Island gained him fame in London and drew Edward Gibbon Wakefield's attention to his journalistic ability. So he head-hunted FitzGerald to be secretary of the Colonial Reform Society in 1849. When FitzGerald became captivated by the Godley-Wakefield Canterbury Association, however, and announced his desire to be not only a Canterbury colonist but its settlement's leader, Wakefield's sense of betrayal and his disappointment soured into acute dislike; which matured into genuine hatred as FitzGerald in turn became exasperated by Wakefield's continual interference and thwarting of his ambition. Their mutual loathing was to cripple New Zealand's first parliament, although FitzGerald himself must carry the greater blame

Edward Gibbon Wakefield, d1862. Alexander Turnbull Library. for having taken office too impetuously, with too little understanding of Auckland's convoluted politics, and too overweening a confidence in his own abilities.

The first mixed ministry of 1854 was created when FitzGerald, Weld and Sewell joined the officials in a ministry before securing a tolerable agreement on their powers from Acting-Governor Wynyard. It was doomed to failure in part by the flawed nature of each of those first responsible ministers: indecisive Sewell, excitable, honourable but ingenuous Weld, and FitzGerald himself, writing sheaves of legislation late into the night in a whirlwind of activity oblivious to the problems he was bringing upon himself. They were the first responsible ministers only because Superintendent Stafford had promised Nelson that he would not be a member of that first parliament; William Fox had only just returned from Europe and America; and Isaac Featherston had come late to Auckland because his wife was ill. And FitzGerald, by excluding Wakefield from crucial informal meetings, had offended the most experienced, knowledgeable, brilliant but dangerous of all New Zealand's first politicians.

For that story, and so many others, you must await the book (to be published by Hazard Press) which I am at present only half way through. FitzGerald, for all that he was sometimes driven by violent dislikes as much as by passing intellectual infatuations, did sustain high moral values and a genuine aristocratic sense of duty and noblesse oblige. They are difficult concepts for some to understand or appreciate fully in modern and cynical New Zealand but they were realities in their times and we must respect the undeniable fact that they drove those who held them. FitzGerald was an idealist and he was never venal. Poor as he always was, he opposed any remuneration for members of parliament, and beset by debt and almost penniless when he returned to Canterbury after the 1854 session in Auckland, he donated his parliamentary allowance of over $£ 100$ to the Lyttelton Colonists' Society. His vision for New Zealand was a utopian one and he died disillusioned by its failure to survive the dynamic realities of the 19 th-century world. Dryden, again, provides a fitting epitaph:

Blest madman, who could every hour employ,

With something new to wish or to enjoy. 